\title{
用語解説
}

\section{Skew Deviation}

\section{定義}

視軸に対して眼球が垂直方向にずれて一眼が他 眼より上に偏位しているもので，末梢の神経・筋 障害, 眼窩内の機械的要因では説明できないもの である1)。共同性 (concomitant) では，上斜位 (hypertropia) はあらゆる眼位で同じであるが， 非共同性（nonconcomitant）では上斜位は眼位に よって変化する。また，交代性では，例觉ば右方 視で右眼が上斜位を，左方視で左眼の上斜位をと る。稀に，ゆっくり眼位が交代するすのや，偏位 の大きさが変わるものもある2)。

随伴症状として眼球の捻転偏位，本平性偏位， 眼球の傾斜反庆 (ocular tilt reaction; OTR), 捻 転眼振などがある。また，末梢前庭症状，脳幹症 状，小脳症状が合併することがある2)。

原因は耳石一眼反射，耳石一頸反射の不均衡に よる。耳石からの入力が遮断されると $7^{\circ}$ にもな る skew deviation と $25^{\circ}$ にも達寸る眼球捻転が 生ずる。左右の後半規管からの入力の不均衡も skew deviation に関与するが，この場合は眼振 を伴う2)。

\section{同義 語}

斜偏位は skew deviation の和訳で，一側眼は 上外斜位，他側眼は下内斜位となる。HertwigMagendi's sign 恃古く Magendie (1825), Hertwig（1826）により記載されたもので，実験動物 で，中小脳脚，上小脳脚，小脳，下オリーブ核， 前庭神経核, 前庭動眼神経路の障害で一眼が他眼 より上位となる徵候である。しかし，このような 眼球の垂直性の開散は眼球が頭部の両外側にある 動物では頭部の傾斜に対する正常反応であり，七 トの場合とは異なるが，ヒトでも垂直方向に眼位 がずれている時に用いられる11。ヒトでは頭部の 傾きに対してその10\%の大きさの眼球回旋が和こ るが， skew deviation は非常に小さい2)。

\section{鑑別診断}

症状から，1）外眼筋麻㾝。垂直性に働く篎の
麻痺に似ており，特に偏位が眼位によって変わる 場合は鑑別が困難である。中枢や末梢神経症状の 有無が鑑別に役立ち，本症では脳幹や小脳症状， 核間性眼笳麻疩や片側性障害が多(1)，2）水平 性斜視。子供では水平性斜視の前兆として skew deviation がみられることがある，3）病的頭部 傾斜と眼球回旋。上斜位の眼と反対側以頭部が傾 き，眼球が頭部と同じ方向に回旋する。これは生 理的な眼球回旋之は逆である，4）眼球捻転。両 眼で解離することるある。急性発症の skew deviation では眼球捻転が合併する2)

責任病巣は2 ${ }^{2)}$ 5)，1）急性末梢前庭障害5)，2）一 側前庭神経核障害（通常障害側の眼球が下転)1),

3) 小脳障害, 4) 一側性核間性眼筋麻痺（通常 障害側の眼球が上転)，5）中脳障害（通常障害側 の眼球が上転, 反対側に頭部が傾斜)，6）大脳障 害などがある。中脳障害では発作性 skew deviation, 周期性方向交代性 skew deviation などが みられる。てんかんでみられることもある。

\section{文献}

1) Cogan DG: Neurology of the Ocular Muscles, 2nd ed. pp 134-135, Charles C Thomas, Springfield, 1956

2 ) Leigh RJ, Zee DS: The Neurology of Eye Movements, 3rd ed. pp 463-465, Oxford University Press, N.Y, 1999

3 ) Keane JR: Ocular skew deviation. Analysis of 100 cases. Arch Neurol 32: 185-190, 1975

4) Brandt T, Dieterich M: Skew deviation with ocular torsion: A vestibular brainstem sign of topographic diagnostic value. Ann Neurol 33: 528-534, 1993

5 ) Riordan-Eva P, Harcourt JP, et al: Skew deviation following vestibular nerve surgery. Ann Neurol 41: 94-99, 1997

（清水夏繪） 


\section{Tullio 現象}

Tullio 現象とは，音刺激によりめまい感，ある いは眼振などの前庭症状が誘発される徵候を言 5。

1929年 Tullio ${ }^{1)}$ は鳩の半規管に開空をし，音刺 激を与えたところ，鳩に眼振と頭振が出現するこ とを確認した。

当初ヒトに招いてこの反応は半規管に瘦孔を有 する真珠腫性中耳炎や先天性梅毒に特有の瘦孔症 状と同様の現象と考えられていたが，その後メ二 エール病, 遅発性内リンパ水腫, 外傷性中耳損 傷, 外傷性内耳損傷, 先天性中耳奇形, 先天性感 音性難聴などの迷路に瘦孔を有しない様々な疾患 でる報告されるよらになった。

瘦孔が存在しない症例炕ける Tullio 現象の 発生機序としては, 内リンパ水腫による抎張した 膜迷路とあぶみ骨基底板の接触2), 膜迷路とあぶ 又骨底の線維性㾑着 (vestibulofibrosis) ${ }^{3)}$, 先天 奇形や外傷に上るあぶ依骨底の易可動性4)などが 推測されて扣り，何れの場合にる音刺激によるあ ぶみ骨底の振動が内リンパを介して直接前庭の感 覚器を刺激するために眼振やめまい感が誘発され ると考吕られている。また，この反応が惹起され やすい刺激音の周波数は $500 \sim 1000 \mathrm{~Hz}$ の低〜中 音域であり, 音圧は $70 \mathrm{dBnHL}$ 以上とされてい る。

Tullio 現象により誘発される微細な眼球運動を 遮眼状態で ENG 記録する方法は sono-ocular test と呼ばれている。音刺激中は患側向きに眼振が認 められることが多く, 刺激終了後は眼振が健側向 さに変化する症例もある。その他, 回旋眼振を観 察した例や，眼振ではなく健側方向への眼球偏位 のみを認めたとする報告むある。

一方, Tullio 現象は病的な徵候とは限らず, 正 常者でも出現し得るとの報告もある5)。

最近, 音刺激による前庭誘発筋電位 (Vestibular Evoked Myogenic Potentials: VEMP) が 注目されている。これは正常者に認められる前庭
・頸反射であり，この反応経路としては， click 音刺激により，球形囊が刺激され，それが下前庭 神経から前庭神経核を経由し, さらに同側の頸筋 に至る経路が推定されている。したがって, 同様 な機序で, click 音刺激で球形囊を介して前庭・ 眼反射が若起され，眼振やめまい感が誘発される 可能性がある67)。最近では Tullio 現象の発生機 序の一つをこのように音による球形暴刺激と説明 する報告8)もあり注目される。

\section{文献}

1) Tullio P: Das Ohr und die Entstehung der Sprache und Schrift. Urban und Schwarzenberg, Berlin, 1929

2 ) 内藤 僬: Tullio 現象を呈したメニエール氏 病 3 例. 耳鼻 1: 249-252, 1955

3 ) Nadol JB: Positive fistula sign with an intact tympanic membrane. Arch Otolaryngol 100: 273-278, 1974

4) Kwee HL: A case of Tullio phenomenon with congenital middle-ear abnormalities. J OtoRhino-Laryngol 34: 145-152, 1972

5 ) Erlich MA, Lawson W: The incidence and significance of the Tullio phenomenon in man. Otolaryngol Head Neck Surg 88: 630635,1980

6 ) Fluur E, Mellstrom A: Saccular stimulation and oculomotor reactions. Laryngoscope 80: 1713-1721, 1970

7 ) Curthoys I: Eye movements produced by utricular and saccular stimulation. Aviat Space Environ Med (Suppl 9) 58: A192-197, 1987

8 ) Colebatch JG, Day BL, Bronstein AM, et al: Vestibular hypersensitivity to clicks is characteristic of the Tullio phenomenon. J Neurol Neurosurg Psychiatry 65: 670-678, 1998

(伊藤彰紀) 